\title{
Electrochemical behavior and pH stability of artificial salivas for corrosion tests
}

\author{
Comportamento eletroquímico e estabilidade \\ de $\mathrm{pH}$ de salivas artificiais para testes de \\ corrosão
}

\section{Gláucia Maria Oliveira de Queiroz ${ }^{(a)}$ Leandro Freitas Silva ${ }^{(b)}$ José Tarcísio Lima Ferreira(c) José Antônio da Cunha P. Gomes (d) Lúcio Sathler(d)}

(a) Assistant Professor, Gama Filho University, Rio de Janeiro; Master's degree in Metallurgic Engineering and Materials/ Biomaterials.

(b) Assistant Professor, Veiga de Almeida University, Rio de Janeiro; Master's degree in Metallurgic Engineering and Materials/ Biomaterials.

(c) Professor, Department of Pediatric Clinics, Preventive and Social Dentistry, School of Dentistry of Ribeirão Preto, University of São Paulo; PhD in Metallurgic Engineering and Materials/Biomaterials.

(d) Professor, Program of Metallurgic Engineering and Materials, Coordination of Engineering Graduate Programs (COPPE), Federal University of Rio de Janeiro; PhD in Metallurgic Engineering and Materials.

\begin{abstract}
It is assumed that the compositions of artificial salivas are similar to that of human saliva. However, the use of solutions with different compositions in in vitro corrosion studies can lead dissimilar electrolytes to exhibit dissimilar corrosivity and electrochemical stability. This study evaluated four artificial salivas as regards $\mathrm{pH}$ stability with time, redox potentials and the polarization response of an inert platinum electrode. The tested solutions were: SAGF medium, Mondelli artificial saliva, UFRJ artificial saliva (prepared at the School of Pharmacy, Federal University of Rio de Janeiro, RJ, Brazil) and USP-RP artificial saliva (prepared at the School of Pharmaceutical Sciences of Ribeirão Preto, University of São Paulo, SP, Brazil). It was observed that $\mathrm{pH}$ variations were less than 1 unit during a 50-hour test. The SAGF medium, and the UFRJ and USP-RP solutions exhibited more oxidizing characteristics, whereas the Mondelli solution presented reducing properties. Anodic polarization revealed oxidation of the evaluated electrolytes at potentials below $+600 \mathrm{mV}_{\mathrm{SCE}}$. It was observed that the UFRJ and USP-RP solutions presented more intense oxidation and reduction processes as compared to the Mondelli and SAGF solutions.
\end{abstract}

Descriptors: Saliva, artificial; Hydrogen-ion concentration; Corrosion; Sodium fluoride.

Resumo: Admite-se que as composições das salivas artificiais são semelhantes àquela da saliva humana. A utilização de soluções de composições distintas em estudos de corrosão in vitro, entretanto, pode fazer com que eletrólitos diferentes exibam diferenças no processo corrosivo e na estabilidade eletroquímica. Este estudo avaliou quatro salivas artificiais em relação a estabilidade do pH em função do tempo, potencial redox e resposta à polarização de um eletrodo de platina inerte. As soluções testadas foram: meio SAGF, saliva artificial Mondelli, saliva artificial UFRJ (preparada pela Faculdade de Farmácia da Universidade Federal do Rio de Janeiro, RJ, Brasil) e saliva artificial USP-RP (preparada pela Faculdade de Ciências Farmacêuticas de Ribeirão Preto, Universidade de São Paulo, $\mathrm{SP}, \mathrm{Brasil})$. Foi observado que as variações de $\mathrm{pH}$ foram menores que 1 unidade durante as 50 horas de ensaio. O meio SAGF e as soluções UFRJ e USP-RP exibiram características mais oxidantes, enquanto a solução Mondelli apresentou propriedades redutoras. A polarização anódica mostrou oxidação dos eletrólitos avaliados a potenciais inferiores a $+600 \mathrm{mV}_{\mathrm{ECS}}$. Foi observado que as soluções UFRJ e USP-RP são mais facilmente oxidadas e reduzidas se comparadas com as soluções Mondelli e SAGF.

Descritores: Saliva artificial; Concentração de íons de hidrogênio; Corrosão; Fluoreto de sódio. 


\section{Introduction}

The performance of materials placed in the oral environment should be assessed using artificial saliva of a known composition because natural saliva varies widely. ${ }^{4}$ It is important to underscore that it is impossible to obtain an artificial saliva that reproduces exactly the same characteristics of human saliva, which is very inconsistent and unstable. ${ }^{5}$

Literature reviews about artificial salivas for in vitro studies of dental materials have been conducted. ${ }^{2,4}$ Different formulations have been developed for specific purposes. Some of these formulations use inorganic compounds exclusively, which are used for in vitro studies, while others include organic substances and inorganic compounds $\mathrm{s}^{2,7}$ and are mostly indicated for patients with salivary deficiency. ${ }^{11}$

Duffó, Quezada Castillo ${ }^{1}$ (2004) compared the behavior of 17 artificial salivas to that of human saliva as regards corrosion of copper-aluminum dental alloys. From an electrochemical standpoint, none of the tested artificial salivas had the same effect on the dental alloys as natural human saliva. The authors then formulated a new solution without protein and organic compounds (except for urea and/or organic acids for $\mathrm{pH}$ adjustment) for assessment of four different dental alloys (copperaluminum, 304SS stainless steel, chromium-cobalt alloy and low-copper amalgam alloys). The results showed that the new artificial saliva solution behaved similarly to natural human saliva as regards corrosion of the tested alloys.

The purpose of the present study was to establish oxyreduction and $\mathrm{pH}$ characteristics of artificial salivas, as well as the anodic and cathodic polarization responses of an inert platinum electrode in the studied media.

\section{Material and Methods}

Four artificial salivas were evaluated. Two solutions contained only inorganic compounds: An artificial saliva proposed by Mondelli' ${ }^{6}$ (1995) (hereinafter referred to as Mondelli) and SAGF medium. ${ }^{2}$ The other two contained organic substances and inorganic compounds: One of the solutions (hereinafter referred to as UFRJ) was prepared at the School of Pharmacy, Federal University of Rio de Janeiro, RJ, Brazil, and the other one (hereinafter referred to as USP-RP) was prepared at the School of Pharmaceutical Sciences of Ribeirão Preto, University of São Paulo, SP, Brazil. Both solutions, UFRJ and USP-RP, were evaluated with and without addition of fluoride. The compositions of the tested artificial salivas are given on Table 1.

A 500-mL capacity glass electrochemical cell covered by an acrylic plate with holes was used to affix the following devices: Three platinum electrodes (pure platinum - 99.97\%; Umicore Brasil Ltda., Americana, SP, Brazil) for redox potential measurements; a combined electrode (no. 60714; Cole-Parmer Instrument Company, Vernon Hills,

Table 1 - Composition of the artificial salivas.

\begin{tabular}{|c|c|c|c|c|}
\hline \multirow{2}{*}{ Substances } & \multicolumn{4}{|c|}{ Concentration (mg/1,000 ml) } \\
\hline & Mondelli & SAGF & UFRJ & USP-RP \\
\hline $\mathrm{NaCl}$ & 500 & 125.6 & 674 & 865 \\
\hline $\mathrm{KCl}$ & 500 & 963.9 & 960 & 625 \\
\hline $\mathrm{CaCl}_{2} \cdot 2 \mathrm{H}_{2} \mathrm{O}$ & 795 & 227.8 & 116.8 & 72 \\
\hline Citric acid $(*)$ & 5 & - & - & - \\
\hline $\mathrm{Na}_{2} \mathrm{~S} .9 \mathrm{H}_{2} \mathrm{O}\left({ }^{*}\right)$ & 5 & - & - & - \\
\hline $\mathrm{NaH}_{2} \mathrm{PO}_{4} \cdot \mathrm{H}_{2} \mathrm{O}$ & 780 & - & - & - \\
\hline $\mathrm{KH}_{2} \mathrm{PO}_{4}$ & - & 654.5 & - & 362 \\
\hline $\mathrm{KH}_{2} \mathrm{PO}_{4} \cdot \mathrm{H}_{2} \mathrm{O}$ & - & - & 274 & - \\
\hline $\mathrm{K}_{2} \mathrm{HPO}_{4}$ & - & - & - & 802 \\
\hline Urea & 1,000 & 200.0 & - & - \\
\hline$\left(\mathrm{NH}_{4}\right)_{2} \mathrm{SO}_{4}$ & 300 & - & - & - \\
\hline $\mathrm{NH}_{4} \mathrm{Cl}$ & - & 178.0 & - & - \\
\hline $\mathrm{NaHCO}_{3}$ & 100 & 630.8 & - & - \\
\hline KSCN & - & 189.2 & - & - \\
\hline $\mathrm{Na}_{2} \mathrm{SO}_{4} \cdot 10 \mathrm{H}_{2} \mathrm{O}$ & - & 763.2 & - & - \\
\hline $\mathrm{MgCl}_{2} \cdot 6 \mathrm{H}_{2} \mathrm{O}$ & - & - & 40.8 & 125 \\
\hline NaF (optional) & - & - & 42 & 4.25 \\
\hline Methyl Paraben & - & - & 1,000 & - \\
\hline Sorbitol 70\% & - & - & 24,000 & 42.7 \\
\hline Carboxymethylcellulose & - & - & 8,000 & - \\
\hline Nipagin/Nipasol & - & - & - & $10(\mathrm{~mL})$ \\
\hline Sodium Benzoate & - & - & - & $10(\mathrm{~mL})$ \\
\hline Hydroxyethylcellulose & - & - & - & 5,000 \\
\hline
\end{tabular}

$\left.{ }^{*}\right)$ To be added at the moment of use. 
Table 2 - Concentration of the inorganic constituents of the artificial salivas.

\begin{tabular}{|c|c|c|c|c|c|c|c|c|c|c|c|c|}
\hline \multirow{2}{*}{$\begin{array}{l}\text { Artificial } \\
\text { Saliva }\end{array}$} & \multicolumn{12}{|c|}{ Concentration $\left(10^{-3} \mathrm{Mol}\right)$} \\
\hline & $\mathrm{Na}^{+}$ & $\mathrm{K}^{+}$ & $\mathrm{Ca}^{2+}$ & $\mathrm{NH}^{4+}$ & $\mathrm{Mg}^{2+}$ & $\mathrm{Cl}^{-}$ & Total P & Total $\mathrm{CO}_{3}$ & $\mathrm{SCN}^{-}$ & $\mathrm{S}^{2-}$ & $\mathrm{F}^{-}$ & $\mathrm{SO}_{4}{ }^{2-}$ \\
\hline Mondelli & 15.42 & 6.71 & 5.40 & 4.54 & - & 26.06 & 5.65 & 1.19 & - & 0.02 & - & 2.27 \\
\hline SAGF & 14.48 & 19.69 & 1.55 & 3.33 & - & 21.51 & 4.81 & 7.51 & 1.95 & - & - & 2.37 \\
\hline UFRJ & 11.52 & 14.65 & 0.79 & - & 0.20 & 26.38 & 1.77 & - & - & - & 1.00 & - \\
\hline USP-RP & 14.88 & 20.25 & 0.48 & - & 0.61 & 25.36 & 7.26 & - & - & - & 0.10 & - \\
\hline
\end{tabular}
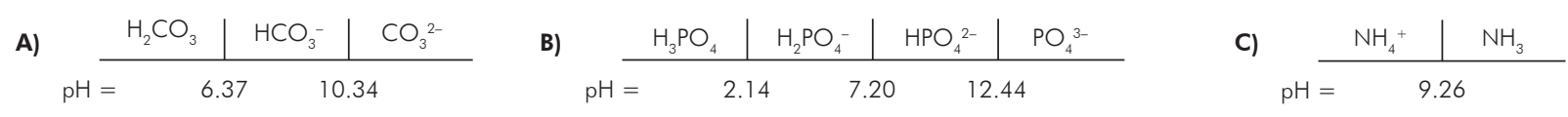

Figure 1 - $\mathrm{pH}$ bands at which the species on Table 2 presented chemical prevalence in the carbon- $\mathrm{H}_{2} \mathrm{O}(\mathbf{A})$, phosphorus- $\mathrm{H}_{2} \mathrm{O}$ (B) and nitrogen $-\mathrm{H}_{2} \mathrm{O}$ systems (C).

IL, USA) for $\mathrm{pH}$ measurements; a flat platinum electrode $\left(0.36 \mathrm{~cm}^{2}\right)$ for anodic and cathodic polarization; a saturated calomel electrode reference (SCE) (model R-682; Analion Comércio e Indústria Ltda., Ribeirão Preto, SP, Brazil); an immersion heater to maintain temperature at $37^{\circ} \mathrm{C} ;{ }^{3}$ a thermometer and devices for gas entrance and exit. The essays were performed in solutions agitated by a magnetic stirrer. Anodic and cathodic polarizations were performed starting at open circuit potential, with manual variation of the potential (increasing in $20 \mathrm{mV}$ steps). A PG-05 Ohminimetra Potentiostat-Galvanostat apparatus (Omnimetra Instrumentos, Nova Friburgo, RJ, Brazil) was used. Before each polarization, the platinum electrodes were immersed in a concentrated $\mathrm{HCl}$ solution for 10 minutes and then washed with distilled water. The SAGF solution was employed both in natural aeration condition and in de-aeration condition by continuous bubbling of a gas mixture $(95 \%$ $\left.\mathrm{N}_{2}+5 \% \mathrm{CO}_{2}\right)$. The other solutions were employed in natural aeration conditions.

The conditions for chemical reaction balance were established using the free energy values available in the Outokumpu HSC Chemistry software for Windows, version 3.0 (Outokumpu Research Oy, Pori, Finland), and the US National Bureau of Standards (NBS) Technical Note 270-3 (US Government Printing Office, Washington, DC, USA).
The total concentration of dissolved main inorganic constituents of the tested salivas is shown on Table 2.

\section{Results}

Figure 1 ( $\mathrm{pH}$ bands for the species on Table 2) indicates the $\mathrm{pH}$ range at which the species on Table 2 presented chemical prevalence in the carbon $-\mathrm{H}_{2} \mathrm{O}$, phosphorus $-\mathrm{H}_{2} \mathrm{O}$ and nitrogen- $\mathrm{H}_{2} \mathrm{O}$ systems. The $\mathrm{pH}$ values of the artificial salivas measured within the 50-hour essay are presented on Table 3 and Graph 1.

The redox potential ranges for the artificial salivas in approximately 50 hours of essay are given on Graph 2. Table 4 presents the maximum and minimum potential values for the solutions.

The artificial salivas were evaluated regarding their oxidizing (Graph 3) and reducing (Graph 4) characteristics by the polarization of a platinum $(\mathrm{Pt})$ electrode immersed in the medium.

Table 5 exhibits the results for open circuit potential $\left(\mathrm{E}_{\mathrm{i}=0}\right)$ of the platinum electrode and the polarization range where the current is null.

\section{Discussion}

The species on Figure 1 characterize the buffer capacity of the solution and stabilize the $\mathrm{pH}$ around a certain value in the artificial saliva. The relative prevalence of the constituents was determined sepa- 
Table 3 - $\mathrm{pH}$ values of the artificial salivas within the 50 hour essay.

\begin{tabular}{l|c}
\multicolumn{1}{c|}{ Artificial Saliva } & pH \\
\hline Mondelli & 5.4 to 5.7 \\
\hline SAGF & 6.8 to 7.8 \\
\hline SAGF with $\left(95 \% \mathrm{~N}_{2}+5 \% \mathrm{CO}_{2}\right)$ & 6.6 to 6.7 \\
\hline UFRJ & 5.9 to 6.3 \\
\hline UFRJ with $\mathrm{F}^{-}$ & 5.8 to 6.1 \\
\hline USP-RP & 6.7 to 6.9 \\
\hline USP-RP with $\mathrm{F}^{-}$ & 6.2 to 6.7 \\
\hline
\end{tabular}

rately for the carbon- $\mathrm{H}_{2} \mathrm{O}$, phosphorus- $\mathrm{H}_{2} \mathrm{O}$ and nitrogen $-\mathrm{H}_{2} \mathrm{O}$ systems at $25^{\circ} \mathrm{C}$, referred to the $\mathrm{pH}$.

Assuming that the $\mathrm{pH}$ of the solutions is buffered by the balance of the above-mentioned ions (Figure 1) and that it ranges from 6 to 7 , then the prevailing species would be $\mathrm{H}_{2} \mathrm{CO}_{3}$ and $\mathrm{HCO}_{3}^{-}$for "Total $\mathrm{CO}_{3}$ ", $\mathrm{H}_{2} \mathrm{PO}_{4}^{-}$for "Total $\mathrm{P}$ " and $\mathrm{NH}_{4}{ }^{+}$for the ammonium salts.

Interpretation of the experimental results obtained here takes into account the "Total $\mathrm{CO}_{3}$ " constituent because the dissociation of the $\mathrm{NaHCO}_{3}$ reagent may produce carbon dioxide $\left(\mathrm{CO}_{2}\right)$, carbonic acid $\left(\mathrm{H}_{2} \mathrm{CO}_{3}\right)$ and $\mathrm{HCO}_{3}^{-}$and $\mathrm{CO}_{3}{ }^{2-}$ carbonates, which are thermodynamically stable carbon forms in water and in aqueous solutions. ${ }^{8}$ The $\mathrm{pH}$ and $\mathrm{CO}_{2}$ partial pressure determine which form will prevail. Similarly, the "P total" constituent represents the different phosphorus forms that are thermodynamically stable in water and aqueous solutions, namely phosphoric acid $\left(\mathrm{H}_{3} \mathrm{PO}_{4}\right)$ and $\mathrm{H}_{2} \mathrm{PO}_{4}^{-}, \mathrm{HPO}_{4}{ }^{2-}, \mathrm{PO}_{4}{ }^{3-}$ phosphate ions. ${ }^{9}$ The relative stability domains of these species are on the electrochemical equilibrium diagram for the phosphorus $-\mathrm{H}_{2} \mathrm{O}$ system at $25^{\circ} \mathrm{C} .^{8}$ As regards the $\mathrm{NH}_{4}{ }^{+}$ion, the ammoniac solutions contain essentially $\mathrm{NH}_{4}{ }^{+}$for $\mathrm{pH}$ values below $9.26 .{ }^{10}$

The first issue to be decided for obtaining an optimal formulation for in vitro tests is the presence of an organic fraction in the mixture. Organic components respond for the viscosity of the solution, which in turn influences the diffusion rates which ultimately influence the kinetics of the reaction. Artificial salivas developed for chemical and electrochemical studies usually lack the viscosity of human
Table 4 - Redox potential range for the tested artificial salivas.

\begin{tabular}{l|c}
\hline \multicolumn{1}{c|}{ Artificial Saliva } & Redox potential $(\mathrm{mV})_{\text {SCE }}$ \\
\hline Mondelli & -238 to +205 \\
\hline SAGF & +261 to +115 \\
\hline SAGF with $\left(95 \% \mathrm{~N}_{2}+5 \% \mathrm{CO}_{2}\right)$ & +150 to +218 \\
\hline UFRJ & +191 to +234 \\
\hline UFRJ with $\mathrm{F}^{-}$ & +275 to +322 \\
\hline USP-RP & +101 to +213 \\
\hline USP-RP with $\mathrm{F}^{-}$ & +150 to +219 \\
\hline
\end{tabular}

Table 5 - Open circuit potential $\left(\mathrm{E}_{\mathrm{i}=0}\right)$ and null current potential range of the polarization curves.

\begin{tabular}{|c|c|c|c|c|}
\hline \multirow{2}{*}{$\begin{array}{l}\text { Artificial } \\
\text { Saliva }\end{array}$} & \multicolumn{2}{|c|}{ Anode Polarization } & \multicolumn{2}{|c|}{ Cathode Polarization } \\
\hline & $\begin{array}{c}E_{i=0} \\
(m V)_{S C E}\end{array}$ & $\begin{array}{c}\text { Potential range } \\
(\mathrm{mV})_{\text {SCE }}\end{array}$ & $\begin{array}{c}E_{i}=0 \\
(m V)_{S C E}\end{array}$ & $\begin{array}{l}\text { Potential range } \\
(\mathrm{mV})_{\text {SCE }}\end{array}$ \\
\hline Mondelli & -7 & -7 to +130 & -50 & -50 to -130 \\
\hline SAGF & +160 & +160 to +310 & +168 & +168 to +80 \\
\hline $\begin{array}{l}\text { SAGF } \\
\text { with } \mathrm{CO}_{2}\end{array}$ & +215 & +215 to +300 & +266 & +266 to +210 \\
\hline UFRJ & +292 & +292 to +310 & +292 & +292 to +280 \\
\hline $\begin{array}{l}\text { UFRJ } \\
\text { with } F^{-}\end{array}$ & +314 & +314 to +328 & +337 & +337 to +314 \\
\hline USP-RP & +171 & +171 to +190 & +171 & +171 to +160 \\
\hline $\begin{array}{l}\text { USP-RP } \\
\text { with F- }\end{array}$ & +200 & +200 to +210 & +200 & +200 to +180 \\
\hline
\end{tabular}

saliva because of the practical difficulties to obtain the proper material.

Addition of sulfides to artificial salivas is advisable for simulating the medium conditions when studying the tarnishing of alloys containing copper $\left(\mathrm{Cu}_{2} \mathrm{~S}\right.$ and $\left.\mathrm{CuS}\right)$ and silver $\left(\mathrm{Ag}_{2} \mathrm{~S}\right) .^{7}$

The use of SAGF medium requires special care because this solution is over-saturated by carbon dioxide relative to air. Consequently, the solution tends to lose $\mathrm{CO}_{2}$ gas, which increases the $\mathrm{pH}$. Before each experiment, the solution's $\mathrm{pH}$ must be adjusted by bubbling purified $\mathrm{CO}_{2}$ gas $(\mathrm{pH}=6.8) .{ }^{2}$

The $\mathrm{pHs}$ of the artificial salivas were measured over time (Graph 1) to evaluate their stability in corrosion essays for longer periods of time. As a rule, $\mathrm{pH}$ was practically constant, varying less than 0.5 


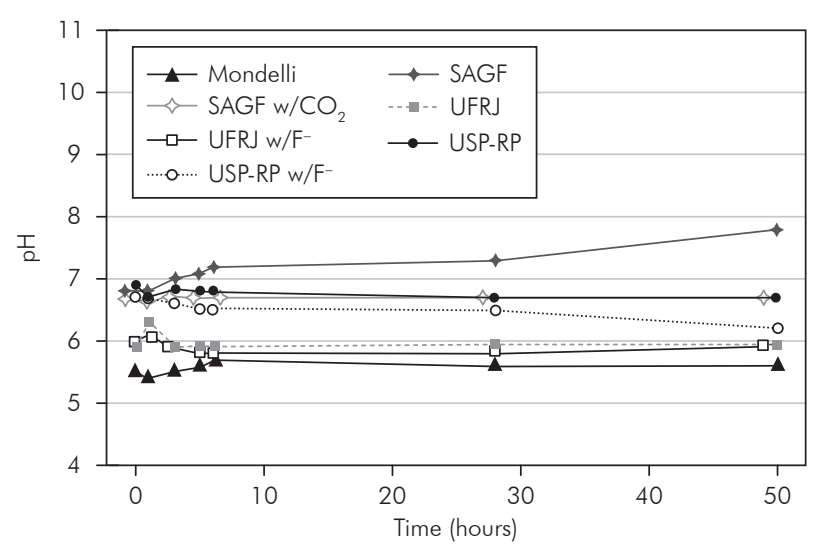

Graph 1 - pH versus time curves for the artificial salivas.

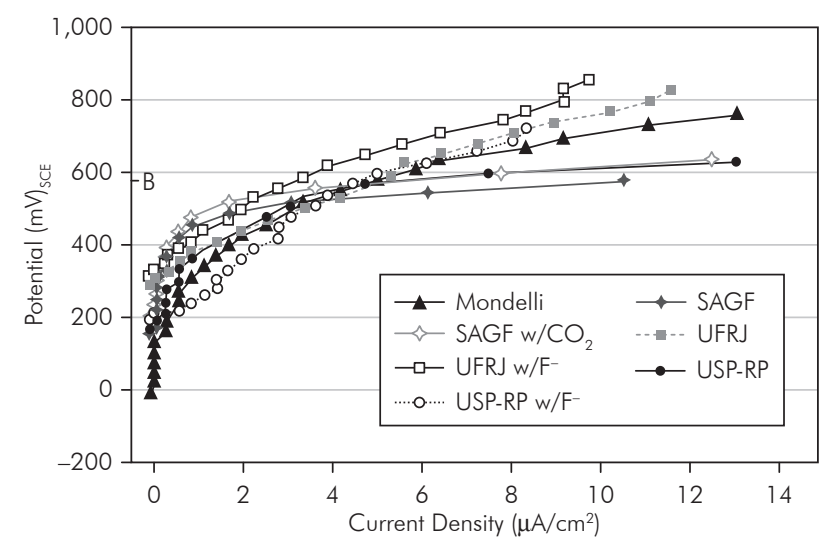

Graph 3 - Anode polarization curves of a platinum electrode in the Mondelli, SAGF, UFRJ and USP-RP artificial salivas. " $\mathrm{B}$ " on the vertical axis indicates the $\mathrm{O}_{2} / \mathrm{H}_{2} \mathrm{O}$ balance potential for $\mathrm{pH}=7$ and 1 atm pressure.

units, except for the SAGF medium without gas mixture $\left(95 \% \mathrm{~N}_{2}+5 \% \mathrm{CO}_{2}\right)$ bubbling. A continuous $\mathrm{pH}$ increase was noticed for this solution, ranging from 6.8 to 7.8 in the studied period. Table 3 exhibits the range of values measured in the 50 -hour essay.

According to several authors, ${ }^{2,7,11}$ the most important buffer system in artificial saliva is the $\mathrm{CO}_{2} /$ $\mathrm{HCO}_{3}^{-}$(or $\mathrm{HCO}_{3}^{-} / \mathrm{H}_{2} \mathrm{CO}_{3}$ ) system. Overall, $\mathrm{CO}_{2}$ gas is the most abundant in human saliva, reaching $150 \%(\mathrm{v} / \mathrm{v})$ if the flow rate is strongly stimulated. ${ }^{7}$ Phosphate ions constitute another important buffer system to be included in artificial saliva. These ions act limiting $\mathrm{pH}$ variations in alkaline media avoiding precipitation of low solubility compounds. ${ }^{2}$

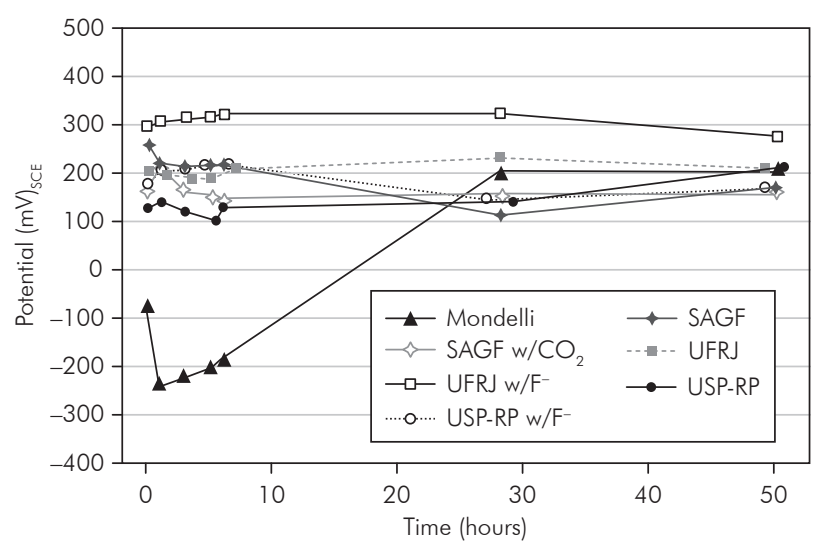

Graph 2 - Redox potential range for the Mondelli, SAGF, UFRJ and USP-RP artificial salivas.

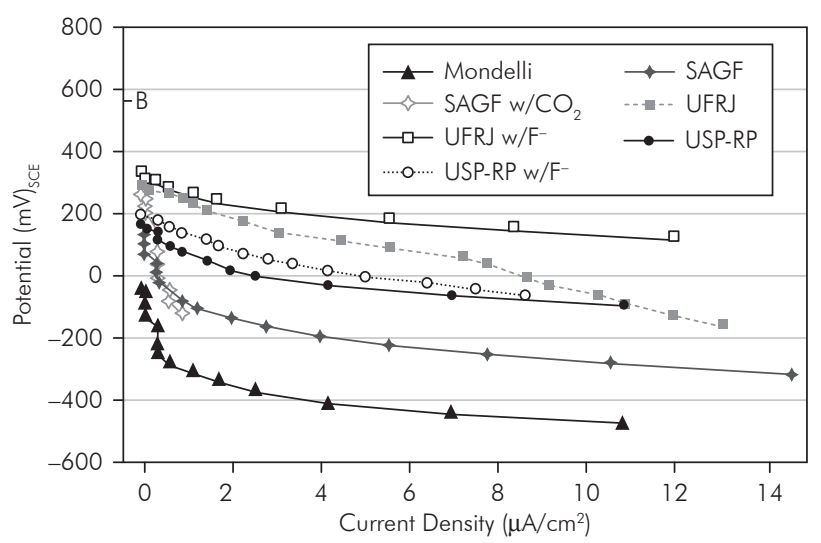

Graph 4 - Cathode polarization curves of a platinum electrode within the Mondelli, SAGF, UFRJ and USP-RP artificial salivas. " $\mathrm{B}$ " on the vertical axis indicates the $\mathrm{O}_{2} / \mathrm{H}_{2} \mathrm{O}$ balance potential for $\mathrm{pH}=7$ and 1 atm pressure.

Among the solutions investigated in this study, the Mondelli and SAGF artificial salivas contain bicarbonate and phosphate buffers, which warrant greater $\mathrm{pH}$ stability on the metal/solution interface. The UFRJ and USP-RP artificial salivas contain only phosphate buffer.

The SAGF medium requires special care. ${ }^{2}$ The results shown on Graph 1 and Table 3 exhibit a continuous $\mathrm{pH}$ increase in the medium without gas mixture bubbling. Conversely, the $\mathrm{pH}$ remained fairly constant along the 50-hour essay for the medium with gas mixture $\left(95 \% \mathrm{~N}_{2}+5 \% \mathrm{CO}_{2}\right)$ bubbling. When the SAGF medium is not bubbled with $\mathrm{CO}_{2}, \mathrm{pH}$ increase may be explained by an imbalance, to the left, of the $\mathrm{CO}_{2}+\mathrm{H}_{2} \mathrm{O}=\mathrm{HCO}_{3}{ }^{-}+\mathrm{H}^{+}$ 
reaction, which means a consumption of $\mathrm{H}^{+}$and a $\mathrm{pH}$ increase.

The redox potential of the Mondelli artificial saliva ranged from -80 to $-238 \mathrm{mV}_{\mathrm{SCE}}$ in the first hour of the essay (Graph 2). Then, the potential increased to $-183 \mathrm{mV}_{\mathrm{SCE}}$ in the sixth hour, finally stabilizing at $+200 \mathrm{mV}_{\mathrm{SCE}}$. The low potential values for the Mondelli solution stem from the addition of $\mathrm{Na}_{2} \mathrm{~S}$ at the beginning of the essay. In fact, sulfides are reducing agents and add reducing characteristics to the medium. In the electrochemical balance diagram exhibited in the study by Valensi et al. ${ }^{12}$ (1974), only the $\mathrm{H}_{2} \mathrm{~S}, \mathrm{HS}^{-}, \mathrm{S}^{2-}, \mathrm{S}, \mathrm{HSO}_{4}{ }^{-}$and $\mathrm{SO}_{4}{ }^{2-}$ forms can be found at balance in a solution. In the absence of oxidizing agents, $\mathrm{H}_{2} \mathrm{~S}$, $\mathrm{HS}^{-}$and $\mathrm{S}^{2-}$ sulfides are stable in water and aqueous solutions for the entire $\mathrm{pH}$ range. In these media, $\mathrm{pH}=7$ is the boundary for the relative predomination domain of $\mathrm{H}_{2} \mathrm{~S} / \mathrm{HS}^{-}$. Conversely, in the presence of oxidizing agents, the sulfides may be oxidized to elementary sulfur $(\mathrm{S})$ or sulfates $\left(\mathrm{HSO}_{4}^{-}, \mathrm{SO}_{4}{ }^{2-}\right)$. In view of this, the increase of potential observed in the present study 1 hour after the start of the essay would be related to the oxidation of sulfides into $\mathrm{S}$ or $\mathrm{SO}_{4}{ }^{2-}$, depending on the oxidizing power of the species in the medium. On the other hand, Graph 2 suggests that sulfide oxidation is fairly slow in media with natural aeration, allowing some corrosion assessments, especially sulfide film formation on the surface of metal dental alloys.

It is not possible to maintain low concentrations of valency 2 sulfides (SII) in the presence of diluted oxygen. ${ }^{2}$ If the sulfide is essential, it should be added immediately before the start of the essay. This recommendation is consistent with that of Mondelli in $1995^{6}$ for the use of artificial saliva containing $\mathrm{Na}_{2} \mathrm{~S} .9 \mathrm{H}_{2} \mathrm{O}$.

The other solutions tested in this study presented oxidizing properties, the oxyreduction potential varying approximately in the +150 to $+300 \mathrm{mV}_{\mathrm{SCE}}$ range (or $\sim+390$ to $+540 \mathrm{mV}$ relative to the standard hydrogen electrode - SHE). In the first six hours of the essay, the solutions containing fluoride (UFRJ and USP-RP) presented oxyreduction potential $100 \mathrm{mV}$ higher then the values measured for the same solutions without fluoride. The UFRJ solution, which has a higher fluoride concentration $\left(1 \times 10^{-3}\right.$
Mol. $\mathrm{L}^{-1}$ ), presented a redox potential $65 \mathrm{mV}$ higher at the end of the essay, while the USP-RP artificial saliva (with $0.1 \times 10^{-3}$ Mol.L $\mathrm{L}^{-1}$ fluoride concentration) showed a lower potential within the 50 -hour period. These results indicate both the fluoride oxidizing power, as stressed by Vanleugenhaghe et al. ${ }^{13}$ (1974) while analyzing the fluorine $-\mathrm{H}_{2} \mathrm{O}$ system at $25^{\circ} \mathrm{C}$, and the trend to fluoride loss after longer exposure periods. The SAGF medium with gas mixture $195 \%$ $\mathrm{N}_{2}+5 \% \mathrm{CO}_{2}$ ) bubbling maintained the redox potential nearly constant from the third hour of the essay $\left(\sim+160 \mathrm{mV}_{\mathrm{SCE}}\right)$. The aerated SAGF medium exhibited a higher initial potential, but in the end evolved to the same value found for the medium containing $\mathrm{CO}_{2}$.

Polarization of an inert electrode (platinum) permits checking whether the species present in the solutions are subject to oxidation or reduction within the investigated potential range. Considering that with $\mathrm{pH}=7$ and $1 \mathrm{~atm}$ pressure water is thermodynamically stable between $-0.413 \mathrm{~V}_{\mathrm{EHS}}$ and $+0.814 \mathrm{~V}_{\mathrm{EHS}}$ $\left(-654 \mathrm{mV}_{\mathrm{SCE}}\right.$ and $\left.+573 \mathrm{mV}_{\mathrm{SCE}}\right)$, the currents resulting from polarization in the water stability domain may be considered as reduction or oxidation currents of the species dissolved in the solution.

In the Mondelli and SAGF salivas, the first current measurement of $0.1 \mu \mathrm{A}\left(0.27 \mu \mathrm{A} / \mathrm{cm}^{2}\right)$ occurred after a 115 to $180 \mathrm{mV}$ polarization relative to the open circuit potential. Conversely, for the UFRJ and USP-RP solutions, the same current required less than $40 \mathrm{mV}$ (Graph 3). This suggests that the UFRJ and USP-RP solutions present a stronger oxidizing trend when the medium is polarized.

The cathodic behavior of the platinum electrode was similar to the anodic behavior: Approximately 86 to $118 \mathrm{mV}$ polarization was required for a $0.1 \mu \mathrm{A}$ $\left(0.27 \mu \mathrm{A} / \mathrm{cm}^{2}\right)$ measurement for the Mondelli and SAGF solutions, while for the UFRJ and USP-RP solutions the same current required a much lower potential ( 30 mV) (Graph 4).

Table 5 shows that each solution presents a platinum polarization potential range where the current is near to zero or less than $0.27 \mu \mathrm{A} / \mathrm{cm}^{2}$. This range was wider for the Mondelli $\left(-130\right.$ to $130 \mathrm{mV}_{\mathrm{SCE}}$ ), SAGF (80 to $310 \mathrm{mV}_{\mathrm{SCE}}$ ) and SAGF with $\mathrm{CO}_{2}(210$ to $300 \mathrm{mV}_{\mathrm{SCE}}$ ) artificial salivas. For the other solutions, the potential range was sensibly smaller, i.e., 
280 to $310 \mathrm{mV}_{\text {SCE }}$ for the UFRJ solution, 314 to $328 \mathrm{mV}_{\mathrm{SCE}}$ for the UFRJ artificial saliva with $\mathrm{F}^{-}, 160$ to $190 \mathrm{mV}_{\mathrm{SCE}}$ for the USP-RP solution and 180 to $200 \mathrm{mV}_{\mathrm{SCE}}$ for the USP-RP solution with $\mathrm{F}^{-}$.

The above-mentioned polarization results indicate that the tested solutions are subject to oxidation and reduction processes, according to the polarization potential of a platinum electrode. It should be noticed, however, that for metal or non-noble alloy electrodes the polarization might indicate the process in either the metal or the solution. For example, in the anode polarization, the current may indicate either metal dissolution or solution oxidation. Any residual ions present in the distilled water used for washing the electrodes did not interfere with the electrochemical characteristics of the tested solutions (and consequently with the results of the present study) because all solutions already contain several ions in their compositions (Table 2).

The artificial salivas evaluated in this study have different electrochemical behaviors and $\mathrm{pHs}$. These

\section{References}

1. Duffó GS, Quezada Castillo E. Development of an artificial saliva solution for studying the corrosion behavior of dental alloys. Corrosion. 2004;60(6):594-602.

2. Gal JY, Fovet Y, Adib-Yadzi M. Review: about synthetic saliva for in vitro studies. Talanta. 2001;53(6):1103-15.

3. Kedici SP, Aksut AA, Kiliçarslan MA, Bayramoglu G, Gokdemir K. Corrosion behaviour of dental metals and alloys in different media. J Oral Rehabil. 1998;25(10):800-8.

4. Leung VW, Darvell BW. Artificial salivas for in vitro studies of dental materials. J Dent. 1997;25(6):475-84.

5. Mandel IR. Relation of saliva and plaque to caries. J Dent Res. 1974;53(2):246-66.

6. Mondelli J. Ligas alternativas para restaurações fundidas. São Paulo: Editorial Médica Panamericana; 1995.

7. Mueller HJ. Tarnish and corrosion of dental alloys. In: ASM International. Handbook Committee. Metals Handbook. Corrosion. Volume 13. $9^{\text {th }}$ ed. Ohio: ASM International; 1987.

8. Muylder JV, Pourbaix M. Carbon. In: Pourbaix M. Atlas of electrochemical equilibria in aqueous solutions. $2^{\text {nd }}$ ed. characteristics must be taken into account when performing in vitro tests to evaluate corrosion resistance of dental alloys, for instance.

\section{Conclusions}

It may be concluded that the results obtained using simple procedures like the immersion of metallic specimens should consider the difference of redox potentials recorded. In addition, interpretation of the polarization responses of metallic electrodes must take into account the electrochemical stability of the artificial saliva within the potential range imposed to the material. Variations of $\mathrm{pH}$ during longterm exposures of the specimens must be considered, as the results of the experiments are affected by the $\mathrm{pH}$ of the environment.

\section{Acknowledgements}

The authors are grateful to COPPE (Coordination of Engineering Graduate Programs) and to the COPPETEC Foundation.

Houston: National Association of Corrosion Engineers; 1974. p. 449-57.

9. Muylder JV, Pourbaix M. Phosphorus. In: Pourbaix M. Atlas of electrochemical equilibria in aqueous solutions. $2^{\text {nd }}$ ed. Houston: National Association of Corrosion Engineers; 1974. p. 504-15.

10. Pourbaix M, Zoubov N. Nitrogen. In: Pourbaix M. Atlas of electrochemical equilibria in aqueous solutions. $2^{\text {nd }}$ ed. Houston: National Association of Corrosion Engineers; 1974. p. 493-503.

11. Thylstrup A, Fejerskov O, editors. Textbook of clinical cariology. $3^{\text {rd }}$ ed. Copenhagen: Munksgaard; 2001.

12. Valensi G, Muylder JV, Pourbaix M. Sulphur. In: Pourbaix M. Atlas of electrochemical equilibria in aqueous solutions. $2^{\text {nd }}$ ed. Houston: National Association of Corrosion Engineers; 1974. p. 545-53.

13. Vanleugenhaghe C, Valensi G, Pourbaix M. Fluorine. In: Pourbaix M. Atlas of electrochemical equilibria in aqueous solutions. $2^{\text {nd }}$ ed. Houston: National Association of Corrosion Engineers; 1974. p. 579-89. 